\title{
Effect of Work Compensation and Discipline on Employee Performance in PT. Berjaya Group Medan
}

\author{
Sondang Ni Bulan Marbun ${ }^{1}$, Donna Maryati Panggabean ${ }^{2}$ \\ ${ }^{1}$ Faculty of Economy, Universitas Methodist Indonesia \\ ${ }^{2}$ Faculty of Economy, Universitas Sisingamangaraja XII Tapanuli (UNITA), Indonesia \\ Email: sondangnibulanmarbun@gmail.com
}

\begin{abstract}
:
The purpose of this study was to analyze and determine the extent of the effect of compensation and work discipline on employee performance at PT. Berjaya Group Medan. Through a descriptive method involving 84 respondents, data was collected using a questionnaire. Data processing is done by SPSS using multiple regression analysis. The results show that compensation and work discipline have a regression coefficient which proves the relationship between compensation and discipline on performance at PT. Berjaya Group Medan.
\end{abstract}

Keywords:

compensation; work discipline; employee performance

\section{Introduction}

To be able to face more competitive competition, companies are required to have competent human resources to improve quality and advance their business. Human resources are the most important factor as a driving force in the implementation of all company activities based on their ability and creativity. Considering the importance of human resources that includes the role of management and utilization, several factors are needed to spur the spirit of employee performance through compensation and work discipline.

Compensation is a sensitive thing when it is associated with the feasibility of meeting needs, especially the increasing level of current needs so that the salary provided is still considered insufficient. Work discipline is an attitude of obedience to the rules that exist in an organization / company. Performance is the result of work achieved by a person or group of people in an organization, in accordance with their respective authorities and responsibilities in an effort to achieve the goals of the organization concerned, legally not violating the law and in accordance with norms and ethics.

PT. Berjaya Group Medan is a company engaged in contracting services. The problem of employee performance in terms of achieving maximum output, can be seen from the low level of performance. This is related to the lack of discipline and compensation provided by the company, so that employee performance is not optimal in completing work on time.

\section{Review of Literature}

\subsection{Definition of Compensation}

According to Ardana (2012: 153) "Compensation is anything that is received by employees as a remuneration for their contribution to the company or organization". Meanwhile, according to Hasibuan (2012: 117) "Compensation is all income in the form of money, direct goods received by employees in return for being given to the company". 
According to Veitzal and Sagala (2009: 744) there are 3 indicators of compensation, namely: salary, wages and intensive. Compensation is one of the important factors in influencing employee performance is the existence of fair and equitable compensation. Some of the results of previous studies have empirically confirmed that compensation has a positive and significant effect on employee performance (Ramzan et al. in Hartati, 2020)

\subsection{Definition of Compensation}

According to Singodimedjo (2012: 86) "Discipline is an attitude of willingness and willingness to understand and obey the norms of regulations that apply around him". Meanwhile, according to Veitzal and Sagala (2009: 825) "Work discipline is a tool used by managers to communicate with employees so that they are willing to change a behavior and as an effort to increase awareness and willingness to obey all company regulations and social norms applicable". According to Rivai (2012: 444) there are 5 indicators of discipline, namely: Attendance, adherence to work regulations, adherence to work standards, high level of vigilance and ethical work.

\subsection{Hypothesis}

H1: It is suspected that there is a partial compensation effect on employee performance

H2: It is suspected that there is a partial influence of work discipline on employee performance.

H3: It is suspected that there is a simultaneous effect of compensation and work discipline on performance the employee.

\section{Reseach Method}

The research location is PT. Berjaya Group, Jln. Ngumban Surbakti No. 60 Medan, North Sumatra (20131). Research time is carried out in June to August 2019. The type of data used in this research is quantitative data. Source of data used in this study are primary data and secondary data. The population in this study were all employees at PT. Berjaya Group Medan As many as 106 people. By using the Solvin formula, 84 research samples were obtained. The sampling technique is incidental. Data collection techniques used in this study were: interviews, questionnaires and observations.

There were data analysis methods

1. Classical Assumption Test

2. Methods for Multiple Linear Regression Analysis

By using the formula:

$$
\mathrm{Y}=\mathrm{a}=\mathrm{b} 1 \mathrm{X} 1+\mathrm{b} 2 \mathrm{X} 2+\mathrm{e}
$$

Where:

$\mathrm{Y}=$ Employee Performance

$\mathrm{A}=$ Constant

$\mathrm{b} 1=$ coefficient of regression compensation

b2 $=$ Regression coefficient of work discipline

$\mathrm{X} 1=$ compensation variable

$\mathrm{X} 2=$ Work discipline variable

$\mathrm{e}=$ Standard Error (error rate).

3. Hypothesis Test
a. Validation Test
b. Reliability Test
c. Determination Coefficient Test (Test - R2) 
d. Partial Test (Test - $t)$

e. Simultaneous Significant Test (Test - F)

\section{Result and Discussion}

\subsection{Validity test}

The results of the study have high validity, so every variable used must be tested for accuracy. The method used is to compare the correlation value ( $\mathrm{r}$ count) with $\mathrm{r}$ tables.

\section{a. Test Validity of Variable Compensation (X1)}

Table 1. Compensation Variable Validity Test Results (X1)

\begin{tabular}{|c|c|c|c|}
\hline Statement & $\mathbf{r}_{\text {count }} \mathbf{5 \%}$ & $\mathbf{r}_{\text {table }}$ & Information \\
\hline $\mathrm{X} 1$ & .597 & .215 & Valid \\
\hline $\mathrm{X} 2$ & .654 & .215 & Valid \\
\hline $\mathrm{X} 3$ & .589 & .215 & Valid \\
\hline $\mathrm{X} 4$ & .593 & .215 & Valid \\
\hline $\mathrm{X} 5$ & .440 & .215 & Valid \\
\hline $\mathrm{X} 6$ & .572 & .215 & Valid \\
\hline
\end{tabular}

Source: Processed SPSS (data processed by the author, 2019)

The corrected item-total correlation column shows the correlation between item scores and total item scores that can be used to test the validity of the instrument. In the results it can be seen that the corrected item-total correlation ( $\mathrm{r}$ count) is greater than $\mathrm{r}$ table, so all compensation questions are declared valid.

\section{b. Test the Validity of Working Discipline Variables (X2)}

Table 2. Work Discipline Variable Validity Test Results (X2)

\begin{tabular}{|c|c|c|c|}
\hline Statement & $\mathbf{r}_{\text {count }} \mathbf{5 \%}$ & $\mathbf{r}_{\text {table }}$ & Information \\
\hline $\mathrm{X} 1$ & .303 & .215 & Valid \\
\hline $\mathrm{X} 2$ & .264 & .215 & Valid \\
\hline $\mathrm{X} 3$ & .420 & .215 & Valid \\
\hline $\mathrm{X} 4$ & .634 & .215 & Valid \\
\hline $\mathrm{X} 5$ & .520 & .215 & Valid \\
\hline $\mathrm{X} 6$ & .531 & .215 & Valid \\
\hline $\mathrm{X} 7$ & .343 & .215 & Valid \\
\hline $\mathrm{X} 8$ & .364 & .215 & Valid \\
\hline $\mathrm{X} 9$ & .367 & .215 & Valid \\
\hline $\mathrm{X} 10$ & .395 & .215 & Valid \\
\hline
\end{tabular}

Source: Processed SPSS (data processed by the author, 2019)

The corrected item-total correlation column shows the correlation between item scores and total item scores that can be used to test the validity of the instrument. In the results it can be seen that the corrected item-total correlation ( $\mathrm{r}$ count) is greater than $\mathrm{r}$ table, so that all work discipline questions are declared valid.

\section{c. Test the Validity of Performance Variables (Y)}

Table 3. Performance Variable Validity Test Results (Y)

\begin{tabular}{|c|c|c|c|}
\hline Statement & $\mathbf{r}_{\text {count }} \mathbf{5 \%}$ & $\mathbf{r}_{\text {table }}$ & Information \\
\hline Y1 & .600 & .215 & Valid \\
\hline Y2 & .634 & .215 & Valid \\
\hline Y3 & .710 & .215 & Valid \\
\hline
\end{tabular}




\begin{tabular}{|c|c|c|c|}
\hline Y4 & .640 & .215 & Valid \\
\hline Y5 & .393 & .215 & Valid \\
\hline Y6 & .394 & .215 & Valid \\
\hline Y7 & .446 & .215 & Valid \\
\hline Y8 & .551 & .215 & Valid \\
\hline Y9 & .541 & .215 & Valid \\
\hline Y10 & .674 & .215 & Valid \\
\hline Y11 & .364 & .215 & Valid \\
\hline Y12 & .474 & .215 & Valid \\
\hline
\end{tabular}

Source: Processed SPSS (data processed by the author, 2019)

The corrected item-total correlation column shows the correlation between item scores and total item scores that can be used to test the validity of the instrument. In the results it can be seen that the corrected item-total correlation ( $r$ count) is greater than $r$ table, so that all performance questions are declared valid.

\subsection{Reliability Test}

The reliability test results show the extent to which the results of measurements with these tools can be trusted. The measurement results must be reliable in the sense that they must have a level of consistency and stability.

Table 4. Reliability Test Results

\begin{tabular}{|l|l|c|c|c|}
\hline No & \multicolumn{1}{|c|}{ Variable } & Cronbach's Alpha & Alpha & Information \\
\hline 1. & Information & .809 & 0.60 & Reliabel \\
\hline 2. & Work Discipline & .717 & 0.60 & Reliabel \\
\hline 3. & The performance & .861 & 0.60 & Reliabel \\
\hline
\end{tabular}

Source: Processed SPSS (data processed by the author, 2019)

Based on the reliability test using Cronbach Alpha, all research variables are reliable / reliable because Alpha is greater than 0.60 . Then it can be concluded that compensation, work discipline, performance are declared reliable.

\subsection{Normality Test}

Testing the normality of research data is to test whether in the statistical model the research variables are normally or not normally distributed. To test whether the distribution is normal or not, including using Histogram analysis and Normal Probality Plot.

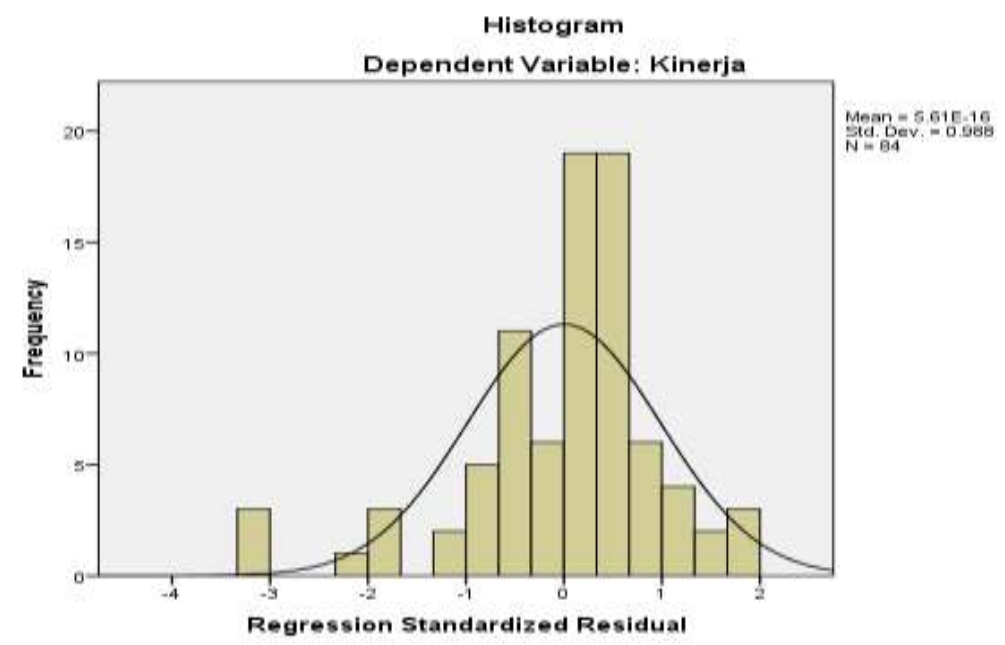

Source: Processed SPSS (data processed by the author, 2019) 


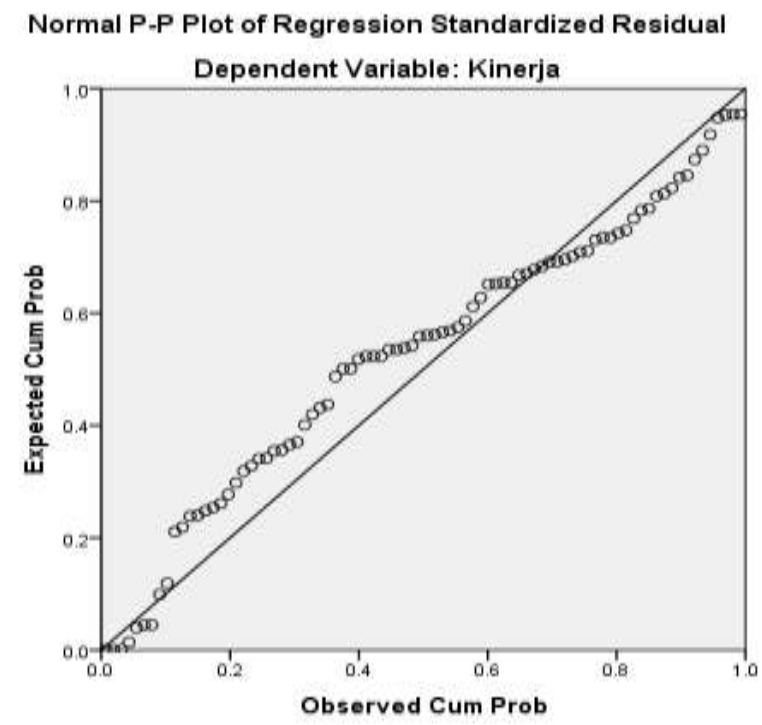

Source: Processed SPSS (data processed by the author, 2019)

Based on the histogram graph in the picture above shows the curve lines tend to be symmetrical, so it can be said that the data is normally distributed. Tests for normality with graphs can be misleading if not careful visually look normal, even though statistically the opposite can be. Therefore it is recommended in addition to the test graph equipped with statistical tests. From the image of the Normal Probability Plot it can be concluded that the image provides a distribution pattern that is close to normal, where the data distribution is around the diagonal line.

\subsection{Multicollinearity Test}

In detecting the presence or absence of multicollinearity symptoms between independent variables in the regression model used Variance Inflation Factors (VIF). Based on the results of SPSS output calculation, the magnitude of VIF of each independent variable can be seen in the table below:

Table 5. Multicollinearity Test Results

Coefficients

\begin{tabular}{|rl|r|r|}
\hline \multicolumn{2}{|l|}{ Model } & \multicolumn{2}{|c|}{ Collinearity Statistics } \\
\cline { 3 - 4 } & \multicolumn{1}{|c|}{ Tolerance } & \multicolumn{1}{|c|}{ VIF } \\
\hline \multirow{2}{*}{1} & Compensation & .726 & 1.377 \\
& Work Discipline & .726 & 1.377 \\
\hline
\end{tabular}

a. Dependent Variable: Kinerja

Source: Processed SPSS (data processed by the author, 2019)

Based on the table above shows that the VIF value $<10$ and Tolerence $>0.10$. So it can be concluded that there is no multicollinearity between compensation and work discipline on performance. Thus the independent variable can be used to predict performance at PT. Berjaya Group.

\subsection{Heteroscedasticity Test}

Heteroscedasticity testing tools can be done with Scatterplot graph analysis tools. Heterokedastisitas test results can be addressed in the picture below: 


\section{Heteroscedasticity Test Results}

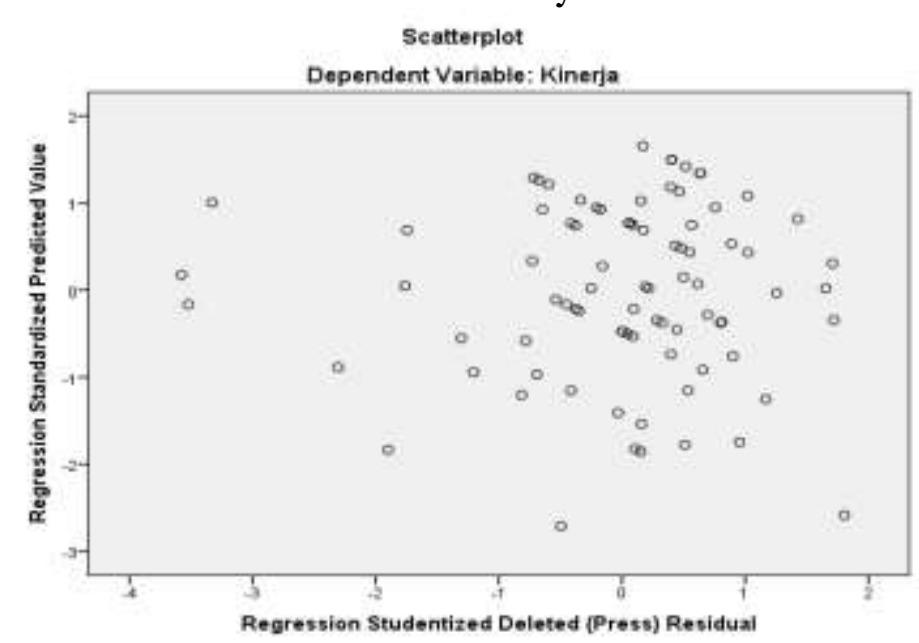

Source: Processed SPSS (data processed by the author, 2019)

Based on scatterplot graphs, heterokedasticity is considered not to occur because the points spread randomly, do not form a certain pattern that is clear and spread either above or below zero on the $\mathrm{Y}$ axis.

\subsection{Multiple Regression Analysis Test}

Table 6. Results of Multiple Regression Analysis Coefficients ${ }^{\mathrm{a}}$

\begin{tabular}{|l|r|r|r|}
\hline Model & \multicolumn{2}{|c|}{ Unstandardized Coefficients } & Standardized Coefficients \\
\cline { 2 - 4 } & \multicolumn{1}{|c|}{ B } & Std. Error & \multicolumn{1}{|c|}{ Beta } \\
\hline (Constant) & -2.060 & 2.665 & \\
Compensation & .647 & .070 & .671 \\
1 Work & .246 & .072 & .249 \\
Discipline & & & \\
&
\end{tabular}

a. Dependent Variable: Performance

Source: Processed SPSS (data processed, 2019)

Based on the table above shows the regression results in order to obtain multiple linear equations as follows:

$$
\begin{gathered}
Y=b_{0}+b_{1} X_{1}+b_{2} X_{2}+e \\
Y=-2,060+0,647 X 1+0,246 X 2+e
\end{gathered}
$$

In this equation, it can be seen that compensation and work discipline have a regression coefficient which proves the relationship between compensation and work discipline on performance at PT. Berjaya Group whose interpretation is as follows:

1. Constant b0 of $-2,060$ states if the performance variable at PT. Berjaya Group is influenced by compensation and work discipline factors of -2,060 units.

2. Coefficient b1 of 0.647 states that each increase in compensation score of 1 unit will affect the performance of 0.521 units where the compensation variable is considered constant.

3. Coefficient b2 of 0.246 states that each increase in work discipline score of 1 unit will affect performance by 0.246 units where the work discipline variable is considered constant. 
Table 7. Partial Hypothesis Results (t Test)

\begin{tabular}{|c|c|c|}
\hline Model & $\mathrm{t}$ & Sig. \\
\hline \multirow{3}{*}{$1 \quad \begin{array}{l}\text { Compensation } \\
\text { Work Discipline }\end{array}$} & -.773 & .442 \\
\hline & 9.186 & .000 \\
\hline & 3.415 & .001 \\
\hline
\end{tabular}

a. Dependent Variable: Performance

Source: Processed SPSS (data processed, 2019)

Based on the above table, partial test results can be obtained as follows:

1. The t-count value for the compensation variable 9,186 is smaller than the t-table value of 1,989 or the significant value for the compensation variable is 0,000 greater than alpha 0.05 . Based on the results obtained, then $\mathrm{H} 0$ is accepted and $\mathrm{H} 1$ is rejected for the compensation variable. Thus partially compensation affects the performance of employees at PT. Berjaya Group Medan.

2. The t-count value for the work discipline variable 3,415 is smaller than the t-table value of 1,989 or the significant value for the work discipline variable 0.001 is greater than the alpha 0.05. Based on the results obtained, then $\mathrm{H} 0$ is accepted and $\mathrm{H} 1$ is rejected for the work discipline variable. Thus partially the work discipline influences the performance of employees at PT. Berjaya Group.

\section{b. Simultaneous Hypothesis Test (Test F)}

Table 8. Simultaneous Hypothesis Results (Test F) ANOVAa

ANOVA $^{\mathrm{a}}$

\begin{tabular}{|l|r|r|r|r|r|}
\hline Model & \multicolumn{1}{|c|}{$\begin{array}{c}\text { Sum of } \\
\text { Squares }\end{array}$} & df & Mean Square & F & Sig. \\
\hline Regression & 809.488 & 2 & 404.744 & 88.734 & $.000^{\mathrm{b}}$ \\
Residual & 369.465 & 81 & 4.561 & & \\
Total & 1178.952 & 83 & & & \\
\hline
\end{tabular}

a. Dependent Variable: Performance

b. Predictors: (Constant), Work Discipline, Compensation

Source: Processed SPSS (data processed, 2019)

In the table above we can see the value of Fcount 88.734 with a significance level of 0.000 . While the value of $\mathrm{F}$ table at $5 \%$ alpha was 3.1049. Therefore, Fcount $>$ Ftable and the significance level of $0.000<0.05$ shows that compensation and work discipline together are positive and significantly influence the performance of PT. Berjaya Group.

\subsection{Determination Coefficient Test (R2)}

Table 9. Results Coefficient of Determination (R2)

Model Summary ${ }^{\mathrm{b}}$

\begin{tabular}{|l|r|r|r|c|}
\hline Model & \multicolumn{1}{|c|}{$\mathrm{R}$} & R Square & Adjusted R Square & $\begin{array}{c}\text { Std. Error of the } \\
\text { Estimate }\end{array}$ \\
\hline 1 & $.829^{\mathrm{a}}$ & .687 & .679 & 2.13572 \\
\hline
\end{tabular}


a. Predictors: (Constant), Work Discipline, Compensation

b. Dependent Variable: The performance

Source: Processed SPSS (data processed, 2019)

The data in the table above shows an R-Square value of 0.687 . This means that $68.7 \%$ of the variation in the value of performance is determined by the role of the variation in the value of compensation and work discipline. So it can be concluded that the contribution value of compensation and work discipline is $68.7 \%$ while $31.3 \%$ is the contribution of other variables not examined such as incentives, bonuses, and salaries.

This is evidenced through the results of partial tests or $t$ tests that compensation has a positive and significant effect on employee performance at PT. Berjaya Group Medan. This effect is seen from the t-count value for the compensation variable 9,186 smaller than the $t$ table value of 1,989 or the significant value for the compensation variable 0,000 is greater than alpha 0.05. Based on the results obtained, then $\mathrm{H} 0$ is accepted and $\mathrm{H} 1$ is rejected for the compensation variable.

\subsection{Effect of Work Discipline on Employee Performance}

Based on the research results obtained that the majority of employees or respondents in this study know about work discipline at PT. Berjaya Group Medan. Good discipline reflects the amount of responsibility someone has for the tasks assigned to him. This encourages work enthusiasm, work morale and the realization of company goals. So, discipline is the key to the success of a company in achieving goals and improving employee performance at the company. According to Veitzal and Sagala (2009: 825), work discipline is a tool used by managers to communicate with employees so that they are willing to change a behavior and as an effort to increase one's awareness and willingness to obey all company regulations and social norms that are apply and improve employee performance.

This is evidenced through the results of partial tests or $\mathrm{t}$ tests that work discipline has a positive and significant effect on employee performance at PT. Berjaya Group Medan. This effect is seen from the t-count value for the work discipline variable 3,415 smaller than the ttable value of 1,989 or the significant value for the work discipline variable 0.001 is greater than the alpha 0.05 . Based on the results obtained, then $\mathrm{H} 0$ is accepted and $\mathrm{H} 1$ is rejected for the work discipline variable.

\section{Conclusion}

From this study it can be concluded that compensation and work discipline have a positive and significant effect on the performance of PT. Berjaya Group. This can be seen from the government as a policy to regulate the growth rate of Civil Servants Candidate. The high interest of the community to become civil servants, and the history of CPNS recruitment policies that are inconsistent. In the 1999-2004 period, the CPNS zero growth policy by only recruiting new Civil Servants Candidate for replacing civil servants who retire, are fired, or resign, so far seen as one of the opportunities to become a civil servant. Despite zero growth, the actual growth of civil servants has never really been zero percent.

1. Multiple regression analysis test which shows that compensation and work discipline has a regression coefficient that proves the relationship between compensation and work discipline on performance at PT. Berjaya Group. This is proven by a). Constant b0 of 2,060 states if the performance variable at PT. Berjaya Group is influenced by compensation and work discipline factors of $-2,060$ units. b) Coefficient b1 of 0.647 states that each increase in compensation score of 1 unit will affect the performance of 
0.521 units where the compensation variable is considered constant. C) Coefficient b2 of 0.246 states that each increase in work discipline score of 1 unit will affect performance by 0.246 units where the work discipline variable is considered constant

2. T test which shows that a). The t-count value for the compensation variable 9,186 is smaller than the t-table value of 1,989 or the significant value for the compensation variable is 0,000 greater than alpha 0.05 . Based on the results obtained, then $\mathrm{H} 0$ is accepted and $\mathrm{H} 1$ is rejected for the compensation variable. b) The t-count value for the work discipline variable 3,415 is smaller than the t-table value of 1,989 or the significant value for the work discipline variable 0.001 is greater than the alpha 0.05. Based on the results obtained, then $\mathrm{H} 0$ is accepted and $\mathrm{H} 1$ is rejected for the work discipline variable.

3. F test that shows the value of Fcount 88,734 with a significance level of 0,000 . While the value of $\mathrm{F}$ table at $5 \%$ alpha was 3.1049. Therefore Fcount $>$ Ftable and the significance level of $0.000<0.05$ shows that compensation and work discipline together positively and significantly influence the performance.

4. Determination Coefficient Test (R2) which shows the R-Square value of 0.687. This means that $68.7 \%$ of the variation in the value of performance is determined by the role of the variation in the value of compensation and work discipline. So it can be concluded that the contribution value of compensation and work discipline is $68.7 \%$ while $31.3 \%$ is the contribution of other variables such as: incentives, bonuses and salaries

\section{References}

Abdullah Aswaja. (2014). Manajemen Kinerja Karyawan, Yogyakarta : Persindo.

Ardana Mujiati. (2012) Manajemen Sumber daya Manusia, Cetakan Pertama, Penerbit PT.Graha Ilmu, Yogyakarta.

Darsono dan Tjantuk Siswandoko. (2011). Manajemen Sumber Daya Manusia, Jakarta : Alfabeta

Handoko Hani. (2013). Manajemen Sumber daya manusia, Jakarta: Bumi Aksara

Hartati, T. (2020). Analysis of Influence of Motivation, Competence, Compensation toward Performance of Employee. Budapest International Research and Critics InstituteJournal (BIRCI-Journal). P. 1031-1038.

Hasibuan, Malayu, SP. (2012). Manajemen Sumber daya Manusia, Edisi Revisi, Jakarta :PT. Bumi Aksara

Ghozali Imam. (2016). Aplikasi Analisis Multivariate dengan SPSS., Edisi 9.Semarang,Universitas Diponegoro.

Gorda I Gusti. (2009) Manajemen sumber Daya Manusia, Cetakan kedua, Denpasar : Astabarata Bali

Mangkunegara Prabu. (2013). Manajemen Sumber daya Manusia Perusahaan, Bandung : PT. Remaja Rosdakarya.

Manullang. (2014). Dasar-Dasar Manajemen, Yogyakarta : Gajah Mada Univ. Press.

Nazir, Moh. (2011). Metode Penelitian, Cetakan 6. Bogor : Penerbit Ghalia Indonesia.

Priansa Donni. (2014) Perencanaan \& Pengembangan SDM, Bandung : Alfabeta.

Rivai Veithzal. (2012). Kepemimpinan dan Budaya Organisasi, Penerbit : Raja Grafindo Persada Jakarta

Sarwono, Jonathan. (2012). Metode Riset Skripsi Pendekatan Kuantitatif, Jakarta: PT.Elx Komputindo

Singodimedjo. (2012). Manajemen sumber Daya Manusia, Edisi pertama, Penerbit Kencana, Jakarta.

Sugiyono. (2012). Metode Penelitian Bisnis. Bandung: Alfabeta.

Supriyanto. ( 2010). Metodelogi Riset Manajemen Sumber Daya Manusia Malang : UIN Maliki Press. 
Sutrisno Edy. (2015). Manajemen sumber Daya Manusia. Jakarta: Erlangga.

Suwanto Priansa. (2013). Manajemen SDM dalam Organisasi Publik dan Bisnis, Cetakan Ketiga, Bandung : Alfabeta.

Veitzal dan Sagala Jauvani. (2009) Manajemen Sumber Daya Manusia Untuk Perusahaan, Jakarta : Rajawali Pers.

Wibowo. (2010). Manajemen Kinerja , Edisi Ketiga, Jakarta : Raja Grafindo Persada Wirawan. (2009). Evaluasi Kinerja Sumber Daya Manusia, Jakarta : Salemba Empat Yani. (2012). Manajemen Sumber Daya Manusia. Jakarta: Mitra Wacana 